Wojciech Zyzak

Pontifical University of John Paul II in Cracow, Poland

\title{
Faith According to Cardinal Joseph Ratzinger
}

\begin{abstract}
The subject of this article is faith according to Cardinal Joseph Ratzinger, the present Pope Benedict XVI. At the beginning the author presents the Cardinal's diagnosis of the state of faith in the contemporary world. Joseph Ratzinger shows both positive and negative features of this state. After having presented the sociological aspect, the author deals with the essence of the faith according to Ratzinger. The further analysis concern the sacramental dimension of the Christian faith. Because the real faith is necessarily the faith of the Church, the article also indicates its communion dimension. The author additionally discusses a very important topic concerning the relation of faith to reason and truth. At the end of the article the reader can find the teaching of Cardinal about the relation between faith and history.
\end{abstract}

\section{Keywords}

Faith, Ratzinger, Bible, history, communion, reason, truth, Church.

\section{Introduction}

The Holy Father Benedict XVI, when he was still a cardinal, was considered to be a consequent defender of the orthodox Catholic faith because of his role as Prefect of the Congregation for the Doctrine of the Faith. His very rich literary works also bear witness that the awakening and strengthening of faith in people is a subject very close to his heart. The commentators of his works notice and emphasize his particular interest in the subject of faith, especially in the context of the pluralistic outlook on the world ${ }^{1}$. The most important part

1 A. F. Utz, Glaube und demokratischer Pluralismus im wissenschaftichen Werk von Joseph Kardinal Ratzinger, Bonn 1989, p. 12. 


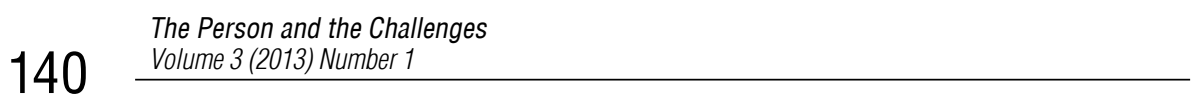

of Ratzinger's scientific researches seems to be the analysis of the relationship between faith and reason ${ }^{2}$. In this context the key criterion for evaluating his outlook is the question of the truth, because resigning from it would mean that man would fall victim to cold calculation, taking into consideration only usefulness ${ }^{3}$. Such a decisive and clear attitude met several times with strong criticism $^{4}$. It has been attempted to reduce his views on the present crisis of the faith included in the interview Rapporto sulla fede (The Ratzinger Report) to a simplified, dualistic view of the world, which outside of the Church would be Satan's domain ${ }^{5}$. Similar attacks on the understanding of the faith by man who nowadays through the will of God has the task to strengthen brothers in the faith, are a good opportunity to take a closer look at this basic religious act in the writings of Joseph Ratzinger.

\section{Diagnosis of the state of faith}

Cardinal Ratzinger was aware of the crisis of the faith in the life of many Christians who, whilst not accepting the authority of the teaching of the Church, repeat the slogan that nowadays orthopraxy, i.e. love for one's neighbour is more important than the orthodoxy ${ }^{6}$. In many societies one can observe the inclination to sacrifice the truth for fashionable and politically correct views, as it is in the case of not allowing the criticism of libertine habits, responsible for the spread of AIDS ${ }^{7}$. The lack of faith leads people to the spiritual emptiness, which many try to fill with stimulants. According to Ratzinger, "big journey", which is undertaken by people using drugs presents a perverse form of pseudo mystic and a sign of the need of infinity. Many people want to replace humble and patient effort of asceticism leading

2 Ibid., p. 18.

3 J. Kreiml, Christlicher Glaube in der Moderne, Regensburg 2000, p. 55.

${ }^{4}$ H. Häring, Theologie und Ideologie bei Joseph Ratzinger, Düsseldorf 2001, p. 21.

5 E. Dufny, Urbi, but not Orbi... the Cardinal, the Chuch, and the Word, "New Blackfriars" 6/1985, p. 281.

6 J. Ratzinger, Rapporto sulla fede, Vittorio Messori a colloquio con il cardinale Joseph Ratzinger, Torino 1985, p. 19.

7 J. Ratzinger, Abbruch und Aufbruch. Die Antwort des Glaubens auf die Krise der Werte, Eichstätter Hochschulreden 61, München 1988, p. 6. 
to the experience of God, with some techniques, avoiding the way of moral and religious development ${ }^{8}$.

The modern people often look into the future and their motto is: progress and not tradition; hope and not faith ${ }^{9}$. In many circles the only moral value is a future perfect society, the creation of which justifies, for instance, experiments on embryos or abortion ${ }^{10}$. Faith in technical progress characterizes the climate of conviction that at some point a better society will be attained. Who does not share this faith is like a former atheist, denying that which keeps the world in progress. The consequence is the need to remove God from the sphere of history to the private area and thus arbitral ${ }^{11}$. Although nowadays nobody believes in unlimited progress like in Enlightenment any more, some faith in a secular messianism still exists in the conscience of many, expressed, for instance, in the following sentence of Ernesto Cardenal: "I believe in history". This is, according to Ratzinger, the faith of Hegel, that history itself will lead to a big synthesis ${ }^{12}$. In this, the author sees the danger of the restoration of Marxism, which will replace the lost Christian faith with dynamism of hope in the social dimension ${ }^{13}$. It is also the main point of Ratzinger's criticism of the Liberation Theology, in which the openness to the world has changed into a naive faith in the science perceived as a "new gospel" without limits and problems ${ }^{14}$. In his opinion the Liberation Theology replaces the faith with fidelity to history ${ }^{15}$. Meanwhile in the East European countries, which experienced Marxism as a force persecuting the Church, there is not such a problem with the orthodoxy of the faith, moreover, a certain form of theology of liberation from Marxism has been born ${ }^{16}$. The Christian faith, from the very beginning, was opposed to the myth of the city of God as a paradise

8 Ibid., pp. 6-8.

9 J. Ratzinger, Glaube und Zukunft, München 1970, p. 99.

${ }^{10}$ J. Ratzinger, Abbruch und Aufbruch. Die Antwort des Glaubens auf die Krise der Werte, Eichstätter Hochschulreden 61, München 1988, pp. 8-10.

${ }^{11}$ J. Ratzinger, Europa - Hoffnungen und Gefahren, Speyer 1990, pp. 14-15.

12 J. Ratzinger, Demokratie - Pluralismus - Christentum, Leutesdorf 1984, p. 9.

13 J. Ratzinger, Europa - Hoffnungen und Gefahren, Speyer 1990, p. 13.

${ }^{14}$ J. Ratzinger, Rapporto sulla fede, Vittorio Messori a colloquio con il cardinale Joseph Ratzinger, Torino 1985, p. 188.

${ }^{15}$ Ibid., p. 194.

${ }^{16}$ Ibid., p. 200. 
on earth, because it has a bigger hope than the political ones ${ }^{17}$. So it is not strange that where the Christian faith weakens, the myth of the city of God rises again, as man cannot give up the totality of hope ${ }^{18}$.

The aforementioned opinions do not mean, that the picture of the state of the faith in the world painted by the current pope is totally negative. For Ratzinger, the new movements which arose spontaneously from the inner vitality of the faith itself, have always been a great sign of hope ${ }^{19}$. In societies themselves he also perceived the rediscovery of morality, emphasizing freedom, justice and peace. Besides, Ratzinger mentioned a new return to religion, striving to concentration, contemplation and contact with sacrum. Nevertheless, in his opinion, the aforementioned social dynamisms can easily turn into esoterism, or remain at the stage of mere romanticism. The obstacle for many people is the necessity of constant inner work based on effort of will and mind, which is characteristic for a true spirituality. Straying from this path leads to the quick satisfaction by the manipulation of feelings. Many also cannot combine the desire of religious experience with the institution of the $\mathrm{Church}^{20}$.

The significant term here seems to be the objective truth. Presently it is strongly questioned especially in the case of moral rules. The false concept of the science has reduced the morality and religion to the subjective sphere, it means created by man. In the evolutionism considering man as a purely natural object of investigation, the optimal conditions of survival of the human race became the basic moral value. Negation of the existence of natural moral law has reduced the world to mere facts. Meanwhile, according to Ratzinger, big moral achievements of humanity have more reason and truth within them, than natural sciences, because they concern more what is essential for the humanity of $\operatorname{man}^{21}$. In the human existence lies obligation, which directs to objective values. Although modern man, knowing the differences among moral and religious systems, has reached the conclusion that they are all human invention, the basic intuition about the moral character of existence is

${ }_{17}$ J. Ratzinger, Kirche, Ökumene und Politik, Einsiedeln 1987, p. 140.

18 J. Ratzinger, Zeitfragen und christlicher Glaube. Acht Predigten aus den Münchener Jahren, Würzburg 1983, p. 76.

19 J. Ratzinger, Rapporto sulla fede, Vittorio Messori a colloquio con il cardinale Joseph Ratzinger, Torino 1985, p. 41.

${ }^{20}$ J. Ratzinger, Abbruch und Aufbruch. Die Antwort des Glaubens auf die Krise der Werte, Eichstätter Hochschulreden 61, München 1988, pp. 10-12.

${ }^{21}$ Ibid., pp. 14-16. 
common for all mankind, similarly to huge moral imperatives ${ }^{22}$. The Author emphatically reminded modern man, that the ethical vision of the Christian faith is in the proper understanding of the word "synthesis" of the big ethical intuitions of mankind. The moral principles are not here of human invention, but discovered in the Revelation and in the moral message of creation ${ }^{23}$.

\section{Searching for the essence of the faith}

In everyday language the word "faith" has two meanings. On the one hand the faith as an opinion means something that precedes knowledge, on the other hand, in the religious meaning, the faith is a certainty going beyond hypothesis and even beyond the certainty of science. It is the certainty giving the sense of life ${ }^{24}$. For cardinal Ratzinger, faith is the basic act of Christian existence, allowing the way to the fullness of humanity to be found ${ }^{25}$. At the first glance, faith seems to be something provisional and temporary. However even in the everyday life, it is a basic attitude, because almost everything has to be accepted with confidence in the knowledge of others. Although it would be better to have knowledge, the society cannot do without faith and confidence of the many, who make use of the knowledge of the few ${ }^{26}$. In the case of the revealed faith, the content remains beyond the reach of man's knowledge. Here is the source of the temptation of agnosticism. Definite atheism in its dogmatic state seems to know too much. Scientific atheism has no sense, because the question about God cannot be answered within the limits of scientific research. In this sense the agnosticism appears more humble. However, in the opinion of the author, the question about God deals not only with theory, but concerns the whole of man's life and that's why the agnosticism cannot be realised in practice. B. Pascal, seeing that the answer cannot be found only theoretically, advises agnostics to take the risk of the hypothesis of God, because only during the experiment is it possible to find

${ }^{22}$ Ibid., pp. 12-13.

${ }^{23}$ Ibid., pp. 16-18.

${ }^{24}$ J. Ratzinger, Weggemeinschaft des Glaubens, Augsburg 2002, pp. 16-17.

${ }^{25}$ J. Ratzinger, Auf Christus Schauen. Einübung in Glaube, Hoffnung, Liebe, Freiburg im Breisgau 1989, pp. 9-10.

${ }^{26}$ Ibid., pp. 11-14. 
out, if it was a good choice. So the agnosticism as a theory can be clear and tempting, but practically, consequently realised it leads to atheism. Because the question of God does not leave a man in neutrality ${ }^{27}$.

In the meantime, faith which comes from hearing is the result of dialog and, different to philosophy, which comes from consideration, it means accepting something that was not thought $\mathrm{up}^{28}$. Faith is not a philosophy but discovery of wisdom, perception and understanding the whole of reality. We believe, not in the moment when an idea takes hold of us, but when we discover that we depend on something which finally is beyond our control ${ }^{29}$. That is why, it is not possible to make somebody believe through talking them into the faith, but it is possible to accept the word of faith as a way and experiment of life, because faith is not only an intellectual acceptance of a truth, but a process encompassing the whole life ${ }^{30}$.

Cardinal Ratzinger, when analysing the essence of faith, draws on the classical text of Saint Thomas Aquinasfrom De veritate q. 14, a. 1. Thomas in the footsteps of Saint Augustine of Hippo defined faith as "thinking with assent". This phrase is a common feature of faith and knowledge. However, while in knowledge certainty determines thinking, in the act of faith, thinking and assent are equal (ex aequo). In faith assent is not given as consequence of evident clarity, but is caused by an act of will. Will, in some way, precedes knowledge and makes us agree with the contents of faith thanks to God's inspiration. Due to this initiative of God, in faith we know that what is not clear for the mind, is true. The result of this, according to Ratzinger, is voluntariness of the act of faith, because faith is possible only as a free act. So faith is an act in which all faculties of the soul cooperate ${ }^{31}$. Here it is evident, why faith comes by hearing and not by understanding. The thinking in the act of faith does not come to an end and peace. The faith is a pilgrimage of thinking, where the mind remains constantly in the act of searching. In the act of faith the mind is "led to the end from the outside, it means in a certain way taken captive". That is why, in spite of strong assent

${ }^{27}$ Ibid., pp. 14-18.

${ }^{28}$ J. Ratzinger, Einführung in das Christentum. Vorlesungen über das Apostolische Glaubensbekenntnis, München 1968, pp. 61-62.

${ }^{29}$ J. Ratzinger, Diener eurer Freude. Meditationen über die priesterliche Spiritualität, Freiburg im Breisgau 1988, p. 45.

${ }^{30}$ J. Ratzinger, Bilder der Hoffnung. Wanderungen im Kirchenjahr, Freiburg im Breisgau 1997, p. 49.

${ }^{31}$ J. Ratzinger, Weggemeinschaft des Glaubens, Augsburg 2002, pp. 18-21. 
of the faith, the contrary movement (motus de contrario) still remains. Because the faith is anticipation of invisible reality, thinking must try to catch up with the assent of the will and overcome motus de contrario. Here the author sees the role of theology as science. Without the anticipation of the faith, thinking would be searching in vain and could not say anything essential about the most important human issues. But anticipating knowledge of the faith does not destroy thinking, which being ex aequo, becomes suitably provoked to creative unrest. Although this unrest of the mind, which is not able to grasp God's word, can turn away from the faith, it is above all the basis of a fruitful journey of thinking to $\operatorname{God}^{32}$. The task of theology indicated in the phrase "credo ut intelligam" consists of accepting the word as a guideline (Vorgabe) and recognising comprehensible sense in it. Such an understanding of theology, according to the author, cannot be lacking on the path of the faith of every believer ${ }^{33}$.

The faith is an act encompassing the whole man. According to the cardinal, it is not enough to believe only theoretically that God exists, but it is necessary to see Him as the most real entity in our life. God should penetrate all layers of human life and fill them completely. The heart must know Him and allow itself to be touched by Him. In difficult situations in our life, God requires trust, it means faith that $\mathrm{He}$ is good. Here we can see that the faith cannot do without other theological virtues, that is hope and charity ${ }^{34}$. Without faith, hope and charity the Church cannot grow ${ }^{35}$. The three theological virtues belong together, because one can understand charity only when it is seen from the side of faith and hope ${ }^{36}$.

\section{The sacramental dimension of faith}

From the previous paragraph it turns out that faith comes from hearing and is not a product of man's own decisions and reflections. Faith is an encounter with something that cannot be invented or caused by man's own effort, because

\footnotetext{
${ }^{32}$ Ibid., pp. 22-25.

${ }^{33}$ Ibid., p. 28.

${ }^{34}$ J. Ratzinger, Auf Christus Schauen. Einübung in Glaube, Hoffnung, Liebe, Freiburg im Breisgau 1989, pp. 109-111.

${ }_{35}$ J. Ratzinger, Kirche, Ökumene und Politik, Einsiedeln 1987, p. 15.

${ }^{36}$ J. Ratzinger, Auf Christus Schauen. Einübung in Glaube, Hoffnung, Liebe, Freiburg im Breisgau 1989, pp. 70-71.
} 
it is a revelation. Cardinal Ratzinger called the structure of this encounter a sacrament ${ }^{37}$. We have already mentioned that faith is an act reaching to the depths of a person, comparable with the final "yes", a definitive acceptance of great love. That's why faith is a grace, just like love is a gift. Similarly to love, faith is a "yes" to God in Jesus Christ, who by his love begins a relation with a believer. Because Jesus allows man to meet him in words and acts of community, sacrament belongs to faith, it means the unification of man's life with the whole history of the relation of God to $\operatorname{man}^{38}$. Faith being something totally personal, leads to the community ${ }^{39}$. That's why cardinal emphasises that the Holy Bible is not a kind of "meteorite fallen from heaven". It contains the thought of God but has been passed on by human history. We can find in it thoughts and life of God's People, which is an essential condition of the uprising and development of the biblical Word ${ }^{40}$. Therefore the original place to experience the Christian confession of faith is the sacramental life of Church. Canon was formed according to this criterion and that's why the Symbol of faith (the creed) is the first instance interpreting Bible. Rules of faith subordinated to the Symbol are the concrete life of believing community. This results that the Magisterium of the Church is not a second authority alongside the Holy Bible, but belongs to it internally. The task of the Magisterium is to secure the Holy Bible from manipulation and saving its unambiguity ${ }^{41}$.

It is worth mentioning here the understanding of sacraments according to cardinal Ratzinger. This understanding takes into consideration the ability to read the Holy Bible not only "backwards" but also "forwards", in its unity of prediction and fulfillment. This is because the understanding of sacraments assumes a historical continuity of God's acting with its concrete place in the shape of the living community of the Church, which is "sacrament in sacraments". It means that the biblical word can only carry and give God's presence if it is not only a word but has a living subject ${ }^{42}$. Sacraments are actions of the Church in which the Church is engaged as the Church, it means

${ }^{37}$ J. Ratzinger, Kirche, Ökumene und Politik, Einsiedeln 1987, p. 19.

${ }^{38}$ J. Ratzinger, Mitarbeiter der Wahrheit. Gedanken für jeden Tag, Würzburg 1990, pp. 215-216.

39 J. Ratzinger, Zeitfragen und christlicher Glaube. Acht Predigten aus den Münchener Jahren, Würzburg 1983, pp. 14-15.

${ }^{40}$ J. Ratzinger, Weggemeinschaft des Glaubens, Augsburg 2002, pp. 29-30.

${ }^{41}$ Ibid., p. 31.

42 J. Ratzinger, „Zum Begriff des Sakramentes“, Eichstätter Hochschulreden 15, München 1979, p. 17. 
not only as an organisation, but on the basis of something not created by the Church itself, giving more than it can give from itself. That's why in sacrament the whole continuum of history, with past, present and future can be met. Sacrament rooted on human history should touch a man in his present time in such a way to open the future beyond death for him. Therefore sacraments are both something new and ancient as Christian and human respectively. Newness of the Christian element and the unity of the human one do not contradict each other. In Jesus Christ the whole creation is accepted and purified. In Him in the mystery of God everything comes to its unity ${ }^{43}$.

In this context it is very important what the author says about each sacrament, especially baptism and Eucharist. Baptism means for him, entering into common form and common confession of faith of the Church in such a way that this faith becomes a personal form of man's life. The content of the faith is spoken in the confession of the Church, which is a common form of faith, leading people through all places and times to the unity. The faith of the Church can be expressed because the human language is able to articulate known and accepted truth ${ }^{44}$. In a similar way, for the author the aim of preparing Eucharistic catecheses was the desire to indicate the proper understanding of the faith in these mysteries, conforming to the faith of Church of all times ${ }^{45}$. In connection with the scene of people leaving Jesus because they did not accept his Eucharistic teaching (J 6, 53. 55) cardinal Ratzinger writes that faith in incarnate God reaches fulfillment only when it becomes incarnate itself as a sacramental event in which incarnate Lord encompasses the corporal existence of $\operatorname{man}^{46}$. This is a source of special interest in liturgy for the cardinal. He reminds Christians that according to the Council, the liturgy is not on the edge but in the heart of the Christian faith ${ }^{47}$. It is in the relation to the liturgy that in his opinion the fate of faith and Church is decided ${ }^{48}$. Where the liturgy does not build a community of faith encompassing the whole of the

\section{${ }^{43}$ Ibid., p. 18.}

${ }^{44}$ J. Ratzinger, Zeitfragen und christlicher Glaube. Acht Predigten aus den Münchener Jahren, Würzburg 1983, pp. 16-17.

45 J. Ratzinger, Eucharistie - Mitte der Kirche, München 1978, pp. 7-8.

${ }^{46}$ Ibid., pp. 51-52.

47 J. Ratzinger, Rapporto sulla fede, Vittorio Messori a colloquio con il cardinale Joseph Ratzinger, Torino 1985, pp. 123-124.

${ }^{48}$ J. Ratzinger, Cantate al Signore un canto nuovo. Saggi di cristologia e liturgia, Milano 1996, p. 9. 
Church with its history, where in it the mystery of living Christ is not visible, there the community celebrates only itself ${ }^{49}$.
\end{abstract}

\title{
4. Communion dimension of faith
}

God's word comes to us through people who have heard and touched Him and know Him from experience. In the faith the element of trust becomes the basis of participation in someone's knowledge. In this way faith creates a web of mutual dependences. The Cardinal the bond with God is also and even firstly a bond among people, based on their communion. But here the openness to God, which allows eternity to come through another man is necessary. In the case of revealed faith many live from this which few have experienced. The few are those who have been given sight. Jesus is the one who sees, whose words come from immediateness with the Father. The Christian faith is by its essence participation in Jesus' sight, given by His word ${ }^{50}$.

The act of faith is a deeply personal act and that's why it's an act of communion, because communion can happen only in the depth of people. The faith is deliverance from the isolation of one's own "ego" towards union with Jesus and people in the Church. That's why faith is necessarily ecclesial faith. True Catholicity means bringing life and faith of the whole Church of all times and places to the present time of a given community ${ }^{51}$. So the structure "we" belongs to the essence of Christianity and being a believer means deliverance from isolation towards "we" - God's children ${ }^{52}$. Cardinal Ratzinger sees the Church in this communion perspective as God's institution. If one sees the Church only as a man-made construction, then the content of the faith seems to be $\operatorname{arbitral}^{53}$. But the aim of the Church is to maintain the truth of the Gospel as a message coming from outside and in its constancy being hope for the people ${ }^{54}$.

49 J. Ratzinger, Aus meinem Leben. Erinnerungen (1927-1977), Stuttgart 1998, p. 174.

${ }^{50}$ J. Ratzinger, Auf Christus Schauen. Einübung in Glaube, Hoffnung, Liebe, Freiburg im Breisgau 1989, pp. 31-34.

51 Ibid., pp. 39-41.

52 J. Ratzinger, Kirche, Ökumene und Politik, Einsiedeln 1987, p. 36.

${ }^{53}$ J. Ratzinger, Rapporto sulla fede, Vittorio Messori a colloquio con il cardinale Joseph Ratzinger, Torino 1985, p. 46.

${ }^{54}$ J. Ratzinger, Demokratisierung der Kirche?, in: Demokratie in der Kirche. Möglichkeiten und Grenzen, Topos plus Taschenbücher, v. 348, Limburg-Kevelaer 2000, pp. 18-19. 
Such a view of the Church has an influence on its relation to the Bible. The Bible itself cannot be the only basis of the Church and the community of the faith. It is Holy Bible because it exists in the living subject of the Church ${ }^{55}$. That's why it's necessary to read the Holy Bible with the faith of the Church. The mere historical explanation does not lead beyond hypotheses and only the faith gives us a certain contemporaneity with Jesus. The faith gives more than hypothesis, because it gives the basis of trust in revealed word ${ }^{56}$. That's why the reading of the Holy Bible must happen in the living faith, in the communion of the Holy Spirit and with taking into consideration the measure given by the Church. In this sense the obedience to the Bible is obedience to the Church. The living word in the living Church is today the actual power of God in the world. The right interpretation of the Bible means reading it where it has made and is making history, where it is not only a witness of the past but a living force of the present ${ }^{57}$.

In this context Ratzinger teaches about the role of the Holy See in the keeping of the unity of the faith in the Church. In his opinion the guidance in the faith must be a guidance in love. The faith without love would not be the faith of Jesus Christ. Only the Eucharistic faith can sustain the Church forever. Therefore the Church is not governed by the majority of votes, but by faith, which matures by encounter with Eucharistic Christ. The Church will be all the more united, the more it lives according to the measure of Eucharist and the more it is in Eucharist faithful to the measure of the faith. On the faith is based the law, order and authority of the Church. In the Church the unity of the faith protects all members and everybody has to follow it. Such an attitude gives more freedom than a majority government, which forces the minority to subordinate to the majority ${ }^{58}$.

\section{Faith in relation to reason and truth}

For cardinal Ratzinger faith means that man does not limit the reality to the visible and tangible things, but looks for another way to reach the reality

55 J. Ratzinger, Der Geist der Liturgie. Eine Einführung, Freiburg i. Br. 2000, p. 144.

${ }^{56}$ J. Ratzinger, Evangelisierung, Katechese und Katechismus, Paderborn 1994, p. 25.

${ }^{57}$ J. Ratzinger, Cantate al Signore un canto nuovo. Saggi di cristologia e liturgia, Milano 1996, pp. 65-66.

58 J. Ratzinger, Bilder der Hoffnung. Wanderungen im Kirchenjahr, Freiburg im Breisgau 1997, pp. $40-43$. 
in which he finds the most important perspective. In the faith he discovers that what is invisible is truly real. The faith is a conversion in which man finds out that he lives in illusion when he pays attention only to the tangible ${ }^{59}$. Faith means acceptance of the truth, that the invisible is more real than the visible. However it is not a blind trust in the irrational, but committing oneself to Logos, "ratio", which means to sense and truth. According to the author faith and reason belong to each other ${ }^{60}$.

Cardinal Ratzinger sees this bond of faith and reason as essential for religion. In his opinion, the ancient pagan religion failed because of the gap between god of faith and god of philosophy, it means god of piety and god of reason. Christianity would have met the same fate if it had separated from the reason. The end of the myth and the victory of the Gospel is the result of the new approach to the relation between religion and philosophy, faith and reason. Christianity, choosing the God of philosophers and identifying Him with God of dialog with men, has shown Him as "agape", the creative power of love ${ }^{61}$. So the synthesis of the biblical faith with the spirit of Hellenism made by Fathers of the Church was, according to the author, necessary. It means that the philosophical truth constitutively belongs to the Christian faith and analogia entis is a necessary dimension of Christian reality ${ }^{62}$. That's why the identification of God of the faith as God of philosophers made by Thomas Aquinas was justifiable. However it does not mean that faith and philosophy are identical or that philosophy can be turned into faith ${ }^{63}$.

For cardinal Ratzinger, the relationship between faith and reason and consequently theology and philosophy is essential. Already in his early work about theology of Bonaventure he notices the dependence of philosophy on faith and theology $y^{64}$. The author has developed this question in the commentary to the encyclical letter of John Paul II Fides et ratio. In his opinion the universality of Christianity is based on the claim of being the truth. There cannot be any contrariety between Christian faith and human reason because

59 J. Ratzinger, Einführung in das Christentum. Vorlesungen über das Apostolische Glaubensbekenntnis, München 1968, pp. 27-28.

${ }^{60}$ Ibid., pp. 40-53.

${ }^{61}$ Ibid., pp. 105-109.

${ }^{62}$ J. Ratzinger, Der Gott des Glaubens und der Gott der Philosophen, München 1960, pp. 24-25.

${ }^{63}$ Ibid., pp. 27-29.

${ }^{64}$ J. Ratzinger, Die Geschichtstheologie des Heiligen Bonaventura, München 1959, pp. 159n. 
both are united by truth. Ratzinger has criticized the separation of faith and reason, which leads to fideism. If the only type of rationality is one of natural science, faith becomes deprived of rationality and pushed into subjectivism ${ }^{65}$. The metaphysical capacity of the reason is a necessary factor of the faith, because a conception of faith developed beyond or against the reason would be insufficient, not only from the point of view of reason, but also from the point of view of faith. That's why the author sees the need of philosophy open to the fundamental questions concerning being. Therefore the Christian faith opposes the theories which negate the human striving to know the metaphysical truth $^{66}$. The faith as acceptance of God's truth revealed in Jesus Christ is no threat for reason and freedom. The faith defends the reason because it needs a seeker of truth. It is not a questioning attitude that is an obstacle to the faith, but an attitude which considers the truth as something unattainable ${ }^{67}$.

According to the cardinal, nothing in the truly scientific vision of the modern world contradicts faith. Faith in the act of creation is today, like never before, actual and should give a view on the greatness of God the Creator. From the true Christology comes the knowing of God and man, as well as the answer to the question of ultimate happiness. Only in the context of faith in the Trinity and incarnate Son the big moral questions of our times find a right answer. But to make it penetrate into the mentality of modern man, it is necessary to create the possibility to experience the faith ${ }^{68}$.

\section{Faith and history}

According to Cardinal Ratzinger, the basic right of a Christian is the right to the whole faith, which is the source of duties for everybody, especially for those holding office, to maintain the entirety of intact faith. In relation to the world, the Church has to defend not only the right to freedom of choice of faith, but also to freedom to believe and live according to it ${ }^{69}$. Faith deals with truth and

${ }^{65}$ J. Ratzinger, L'intervento del Cardinale Joseph Ratzinger, in: Per una lettura dell'Enciclica Fides et ratio, Città del Vaticano 1999, pp. 9-11.

${ }^{66}$ Ibid., pp. 11-12.

${ }^{67}$ Ibid., pp. 14-15.

${ }^{68}$ J. Ratzinger, Cantate al Signore un canto nuovo. Saggi di cristologia e liturgia, Milano 1996, pp. 44-47.

69 J. Ratzinger, Kirche, Ökumene und Politik, Einsiedeln 1987, pp. 180-181. 
the eternal mind of God is the foundation of everything. That is why faith is by itself quaerens intellectum. Here is the source of theology which differentiates Christian faith from other religions. Such a theology is different from philosophy of religion in so far as in its basis lies the word of God which although is logic, goes beyond the possibilities of natural mind and precedes $i t^{70}$. The truth of the faith is not given to an isolated individual but to the community of the Church. Ratzinger emphasises the meaning of Magisterium as the teaching authority of the Church. In the context of historicity of the faith it is worth mentioning the cardinal's opinion that there are some decisions of Magisterium which cannot be the last word in the matter, but are a sign of pastoral wisdom in the form of a single decision. Their core remains right but details, depending on circumstances, can require correction. As an example he gives the antimodernist decisions from the beginning of $20^{\text {th }}$ century. According to the author they remain right as a warning against hasty and superficial adapting to the opinion of the world. These anti-modernist decisions saved the Church from drowning in the liberal world, but in details concerning the content, they ceased to be valid, after they had fulfilled their pastoral role in a given situation ${ }^{71}$.

The historicity of formulation of faith is based on the fact that the human word always remains behind the reality it expresses, all the more when God's reality is expressed in this word. Included in every dogmatic formula is a double insufficiency, that is distance to expressed reality and participation in the human world determined by history. This diminishes the total definiteness of the formula without diminishing the total definiteness of the reality therein. The basis of the unchangeability of dogma is seen by Ratzinger in the authoritative explanation of the Bible, which emphasizes the main directions. The dogma extracts lasting concepts from the multitude of biblical motifs and the author sees in this a particular basis of unchangeability, which, in history, has been connected, not only with the content of dogma, but also with the formula. The dogma, as an explanation, must always be read backwards, looking at what has been explained, that is the Bible. The dogma can be understood only in the unity of the history of dogma ${ }^{72}$.

${ }^{70}$ J. Ratzinger, Zur „,Instruktion über die kirchliche Berufung des Theologen“, „Internationale katholische Zeitschrift Communio"1/1990, pp. 561-563.

${ }^{71}$ Ibid., pp. 563-564.

72 J. Ratzinger, Das Problem der Dogmengeschichte in der Sicht der katholischen Theologie, Köln 1966, pp. 25-28. 
For Ratzinger, in the history of faith it is important to maintain the original sense. For the believer, it is essential that the identity of authentic, original teaching is kept through the centuries. But in the essential historicity of man, this identity can only be kept if it is not a mere identity of a formula passed on externally. The teaching, in order that it maintains its identity, has to be continuously assimilated together with all historical changes of man. Here, decisive is that the believer through the word is led in the relationship with the reality of God, that is, he meets God and not the sum of gained knowledge. The revelation cannot be identified with a certain amount of sentences, because words have an intermediary character in the encounter from which they come and to which they should lead. That's why the revelation requires constant assimilation and explanation. It is concerned with the truth of identity of original teaching ${ }^{73}$. However, the faith, despite having different periods and degrees, is a lasting basis of human existence. Therefore the faith has definitive statements, in which its internal finality is expressed. The symbol of the faith and the dogmas can be submitted to the process of new understanding in the course of history, but in this maturing of understanding the identity of what has been understood cannot be eliminated. This is the basis of definitive finality of the certainty of faith ${ }^{74}$.

$$
* * *
$$

Faith in the publications of Joseph Ratzinger belongs to central themes. He constantly emphasises that only the Christian faith leads to the final sense of reality and to the adequate answers to human basic questions. As we have seen, for the author the faith is an existential act, embracing the whole man. For him important is also its communion and ecclesial nature and its sacramental dimension $^{75}$. As Pope Benedict XVI, he emphasized the importance of the dimension of believing with the Church, trusting that it is led by the Holy Spirit $^{76}$. Being an expert of the Second Vatican Council, Ratzinger, in the

${ }^{73}$ Ibid., pp. 38-39.

${ }^{74}$ J. Ratzinger, Einführung in das Christentum. Vorlesungen über das Apostolische Glaubensbekenntnis, München 1968, p. 217.

${ }^{75}$ A. Bellandi, Fede cristiana come ,stare e comprendere”. La giustificazione dei fondamenti della fede in Joseph Ratzinger, Roma 1996, pp. 361-362.

${ }^{76}$ Benedikt XVI, Begegnung mit den Priestern und Diakonen der Diözese Rom in der Lateranbasilika, 13. 05. 2005, in: Verlautbarungen des Apostolischen Stuhls 168, Der Anfang. Papst Benedikt XVI. Joseph Ratzinger, Bonn 2005, p. 69. 


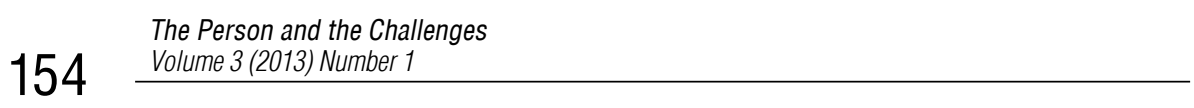

concept of sources of God's revelation, appreciated not only the Holy Bible but also the tradition of the Church ${ }^{77}$. He always ensured the will to remain faithful to the Council, it means, to "today" of the Church, without nostalgia for the past "yesterday" and impatience for "tomorrow" which is not ours ${ }^{78}$. A constant place in the reflection of the author occupies not only the nature of the act of faith with its rational element, but above all the place of the faith in the life of the modern man and the whole culture. In an emphatic and simple manner, the cardinal summarised his opinion in the homily during the Mass Pro eligendo Romano Pontifice 18 April 2005, saying that a mature faith doesn't ride the waves of fashion and the latest news, but is deeply rooted in the friendship with Christ $^{79}$.

\section{Bibliography}

Ratzinger J., Abbruch und Aufbruch. Die Antwort des Glaubens auf die Krise der Werte, Eichstätter Hochschulreden 61, München 1988.

Ratzinger J., Auf Christus Schauen. Einübung in Glaube, Hoffnung, Liebe, Freiburg im Breisgau 1989.

Ratzinger J., Aus meinem Leben. Erinnerungen (1927-1977), Stuttgart 1998.

Ratzinger J., Bilder der Hoffnung. Wanderungen im Kirchenjahr, Freiburg im Breisgau 1997.

Ratzinger J., Cantate al Signore un canto nuovo. Saggi di cristologia e liturgia, Milano 1996.

Ratzinger J., Das Problem der Dogmengeschichte in der Sicht der katholischen Theologie, Köln 1966.

Ratzinger J., Demokratie - Pluralismus - Christentum, Leutesdorf 1984.

Ratzinger J., Der Geist der Liturgie. Eine Einführung, Freiburg i. Br. 2000.

Ratzinger J., Der Gott des Glaubens und der Gott der Philosophen, München 1960.

Ratzinger J., Die Geschichtstheologie des Heiligen Bonaventura, München 1959.

Ratzinger J., Diener eurer Freude. Meditationen über die priesterliche Spiritualität, Freiburg im Breisgau 1988.

Ratzinger J., Einführung in das Christentum. Vorlesungen über das Apostolische Glaubensbekenntnis, München 1968.

Ratzinger J., Eucharistie - Mitte der Kirche, München 1978.

77 J. Ratzinger, Aus meinem Leben. Erinnerungen (1927-1977), Stuttgart 1998, pp. 106-130.

${ }^{78}$ J. Ratzinger, Rapporto sulla fede, Vittorio Messori a colloquio con il cardinale Joseph Ratzinger, Torino 1985, p. 15.

79 J. Ratzinger, Pro eligendo Romano Pontifice, in: Verlautbarungen des Apostolischen Stuhls 168, Der Anfang. Papst Benedikt XVI. Joseph Ratzinger, Bonn 2005, p. 14. 
Ratzinger J., Europa - Hoffnungen und Gefahren, Speyer 1990.

Ratzinger J., Evangelisierung, Katechese und Katechismus, Paderborn 1994.

Ratzinger J., Glaube und Zukunft, München 1970.

Ratzinger J., Kirche, Ökumene und Politik, Einsiedeln 1987.

Ratzinger J., Mitarbeiter der Wahrheit. Gedanken für jeden Tag, Würzburg 1990.

Ratzinger J., Rapporto sulla fede, Vittorio Messori a colloquio con il cardinale Joseph Ratzinger, Torino 1985.

Ratzinger J., Weggemeinschaft des Glaubens, Augsburg 2002.

Ratzinger J., Zeitfragen und christlicher Glaube. Acht Predigten aus den Münchener Jahren, Würzburg 1983.

Ratzinger J., „,Zum Begriff des Sakramentes“, Eichstätter Hochschulreden 15, München 1979. 